\title{
CRYPTOCURRENCY: ACQUISITION AND USAGE
}

\author{
Augustas Subačius \\ Bachelor, Vilnius University, \\ e-mail: subacius.augustas@gmail.com, Lithuania \\ Rasa Subačienè \\ Prof. PhD, Vilnius University, \\ e-mail: rasa.subaciene@evaf.vu.It, orcid.org/0000-0001-6559-8478, Lithuania
}

\begin{abstract}
The article deals with the investigation of acquisition cryptocurrency in time retrospective and aspects of its usage taking point to the change of the value and number of transactions by the most popular cryptocurrency Bitcoin, its usage, comparing with the most popular payment platforms and resources consumed per transaction. The methods of analysis of scientific resources and statistical data, systematisation and critical evaluation were used during the research process. Evaluation of the acquisition and usage of cryptocurrency, according to analysed aspects reveals various sides of the processes.
\end{abstract}

Keywords: cryptocurrency, acquisition of cryptocurrency, usage of cryptocurrency.

DOI: http://dx.doi.org/10.23856/3602

\section{Ivadas}

Technologijų pažanga bei alternatyvių atsiskaitymų formų poreikis sąlygojo kriptovaliutos atsiradimą. O jos išskirtinès savybès, tokios, kaip greitas, pigus bei saugus atsiskaitymas, galimybė ją pasigaminti (iškasti), lèmé ir gana spartų jos populiarejjimą. Tačiau vertinant kriptovaliutos igijimą bei naudojimą, reikètų atsižvelgti ị îvairius šių procesų aspektus.

Tyrimo tikslas - įvertinti kriptovaliutos ịijimo būdus laiko retrospektyvoje bei jos naudojimo aspektus. Tikslui pasiekti buvo naudoti tyrimo metodai: mokslinių šaltinių ir statistinių duomenų analizè, sisteminimas bei kritinis vertinimas.

\section{Kriptovaliutos esmè}

Kriptovaliutos atsiradimas buvo sąlygotas naujų atsiskaitymo formų poreikiu, pritaikant sparčiai besivystančias technologijas. Manytina, jog kriptovaliutų atsiradimui didžiausią įtaką padarè technologinè pažanga. Tačiau nemažiau svarbūs veiksniai tokie, kaip valiutos naudojimo kontrolè, kaina ir finansinių paslaugų kainodara, paskatino ieškoti alternatyvių atsiskaitymo priemonių (Subačius, Subačiené, 2019). Be to, kriptovaliutos naudojimo populiarumą bei tolimesnį vystymąsi sąlygoja tokie veiksniai, kaip pasitikèjimas sistema, paprastumas ir efektyvumas, bankų sistemoje eliminavimas, greitas operacijų vykdymas pasauliniu mastu, žemas išlaidų lygis (Limba, Stankevičius, Andrulevičius, 2019).

Nors kriptovaliutos atsiradimas ir naudojimas yra pakankamai naujas reiškinys, tačiau vis plačiau nagrinėjamas įvairių šalių mokslininkų, apibūdinamas ir vertinamas valstybinių institucijų. Lietuvos bankas kriptovaliutą apibūdina, kaip nereglamentuotus skaitmeninius pinigus, kuriuos galima naudoti kaip atsiskaitymo priemonę, tačiau pabrèžia, jog šiuos pinigus i apyvartą išleidžia ir garantuoja ne centrinis bankas. todèl atsiskaitymai šia valiuta nèra prižiūrimi 
ar reguliuojami (Ispejjimas dèl..., 2014).

A. Mikołajewicz-Woźniak, A. Scheibe (2015) nuomone, kriptovaliutos yra šių dienų pasaulio tendencijų atspindys. Jų augantis populiarumas patvirtina jų tinkamumą šiuolaikinėms problemoms spręsti. Nepaisant to, valdžios institucijos stengiasi išlaikyti pinigų pasaulio kontrolę, priešintis šioms tendencijoms, jų tolesniam augimui. G. Şoavă, A. Mehedințu, C. Sitnikov (2016) teigia, jog dabartinèje globalizacijos eroje, evoliucija informacinèse technologijose ir virtualių rinkų plètra privedè prie naujo būdo keistis virtualioje aplinkoje, kuris yra greitesnis saugesnis ir prieinamas beveik kiekvienam, t. y. kriptovaliuta, pinigai paremti modernia technologija, iš kurios yra tikimasi, didžiulio potencialo verslo pasaulyje. Autoriai kriptovaliutas ịvardija, kaip skaitmeninius pinigus, kurie yra nematerialūs. S. Volosovych, Y. Baraniuk (2018) pateikia nuomonę, jog kriptovaliuta tai skaitmeninis atvaizdavimas vertès, kuri yra išleista ne centrinio banko, skolinančios institucijos ar el. pinigų institucijos, kuri kai kuriais atvejais gali būti naudojama, kaip alternatyva pinigams. Tai fiktyvi valiuta, neturinti oficialaus statuso, tinkamo reguliavimo, išleista, privačių, nefinansinių įmonių, pripažįstama, kaip taisyklè, specifinių virtualių įmonių, neužtikrinančių pinigų grąžinimo bei efektyvios kontrolès. M. A. Nasir, ir kt. (2019) kriptografinę arba skaitmeninę valiutą apibūdina, kaip turtą, kuris egzistuoja tik elektroniniu būdu. Autorių nuomone, populiariausios kriptovaliutos buvo sukurtos atsiskaitymų už sandorius tikslais; tačiau jos dažnai laikomos spekuliaciniais tikslais, tikintis jų vertès kilimo. G. E Karataeva, N. N. Siniavskii (2019) kriptovaliutą ịvardija, kaip virtualius pinigus, kurie neturi fizinès formos. Autoriai pateikia nuomonę, jog tokios valiutos piniginis vienetas yra moneta, o jos išskirtinumas yra apsauga nuo padirbimo, nes joje yra užšifruoti duomenys, kurių negalima dubliuoti (kopijuoti).

Taigi, vertinant skirtinguose šaltiniuose pateiktus kriptovaliutos apibūdinimus, galima išskirti pagrindines kriptovaliutos savybes. Kriptovaliuta galètų būti apibrèžta, kaip skaitmeniniai pinigai ar turtas, kuris yra išreikštas el. būdu. Šios valiutos nekontroliuoja centrinis bankas, todèl jai netaikomas reguliacinis tradicinių pinigų mechanizmas. Tačiau atsiskaitymai kriptovaliuta yra pigesni, saugesni bei greitesni, nors tokios valiutos turèjimas yra susijęs su didžiule nuvertejimo rizika (Subačius, Subačiene, 2019). Remiantis Č. Bartkaus (2019) tyrimo duomenimis, tiesiogiai investuojant į Bitcoin kriptovaliutą, investuotojas rizikuoja, kad investicija nuvertès nuo 18,65\% iki $25,74 \%$ per artimiausias 10 dienų su $99 \%$ tikimybe.

\section{Kriptovaliutos įgijimo būdai}

Viena iš kriptovaliutos išskirtinių savybių yra tai, jog tai yra valiuta, kurią fiziniai ir juridiniai asmenys gali ne tik nusipirkti, bet ir pasigaminti. Pirmame paveiksle pateikiami kriptografinių pinigu igijimo būdai. Kriptovaliutos ịgijimo būdų taikymo vertinimas pateikiamas, atsižvelgiant i populiariausios kriptovaliutos Bitcoin 2013 m.-2019 m. rinkos kapitalizacijos statistinius duomenis.

Kriptovaliutą galima ịgti dviem pagrindiniais būdais: kasimu arba pirkimu (Kuо Chuen, Pak Nian, 2015). Kriptovaliutos kasimas tam nepritaikyta kompiuterine įranga, yra toks šios valiutos kasimas, kai šiam procesui naudojamas kompiuteris, kuris nèra skirtas šiam darbui. Šiuo būdu paprastai kriptovaliuta yra igyjama atsisiuntus kriptografinès valiutos kasimo programinę įrangą i asmenį kompiuterị arba netgi mobilujji telefoną/planšetę, kuri atlieka tam tikras matematines transakcijų iššifravimo ir užšifravimo užduotis, už kurias kasèjas yra apdovanojamas kasamos kriptovaliutos užmokesčiu. Tačiau šis būdas pastaruoju metu tampa nebeefektyvus kriptovaliutos igijimo būdas, kadangi reikalingos užduotys, už kurias yra gaunamas atlyginimas, yra atliekamos per lètai. 


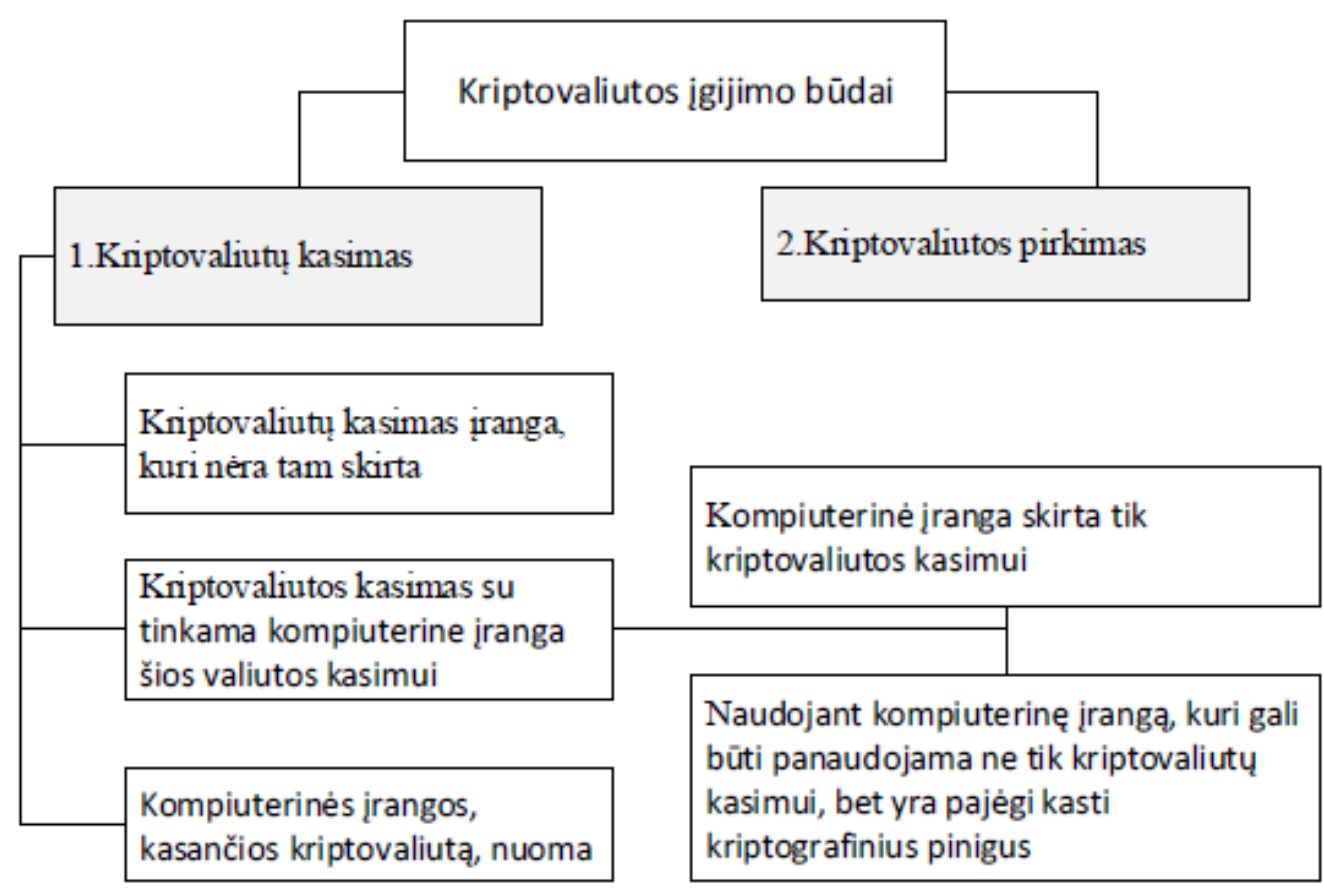

\section{1 pav. Kriptovaliutos ịgijimo būdai}

Sudaryta autorių, remiantis (Kuo Chuen, Pak Nian, 2015)

Tam įtaką daro kriptovaliutos naudojimas. Populiariausios kriptovaliutos Bitcoin statistiniai duomenys (All currencies, 2019) rodo, jog iki $2018 \mathrm{~m}$. sausio mèn. Bitcoin kapitalizacijos norma buvo auganti, kas reiškè ir augančią šių kriptografinių pinigų paklausą, o tai daro tiesioginę ịtaką kriptovaliutos vertei, taip pat ir kriptografinių pinigu kodavimo sudètingumui, didèjant jų kiekiui. Nuo 2013 metų liepos iki 2017 metų liepos šios kriptovaliutos rinkos kapitalizacijos riba išliko pastoviai žema, jos verte šiuo laikotarpiu palyginus su jos verte 2018 m. yra beveik lygi nuliui, tačiau nuo 2017 metų liepos iki 2018 metu sausio yra matomas reikšmingas kapitalizacijos normos padidèjimas, Bitcoin rinkos vertẻ išaugo iki 240 bilijonų doleriu (All currencies, 2019). Šiuo laikotarpiu Bitcoin valiuta išpopuliarèjo, vis plačiau naudojama, kaip atsiskaitymo priemoné, todèl jos vertẻ sparčiai augo. Laikotarpis, nuo 2013 metų liepos iki 2017 metų liepos, buvo palankiausias metas i ją investuoti. Tai sąlygojo palyginus didesni užmokestị už lengviau atliekamas užduotis, kasant šiuos kriptografinius pinigus. Vèliau, nuo 2017 liepos iki 2018 sausio laikotarpis nėra palankus, Bitcoin kasimui su kompiuterine ịranga, kuri nèra pritaikyta šiam procesui. Tam ịtakos dare investavimo ị Bitcoin potencialas ir operacijų kiekio padidejjimas šia valiuta, todèl išaugo šios kriptovaliutos kasimo paklausa, kas sąlygojo mažesni atlygị už tam tikrą atliktų transakcijų skaičiuu, bei padidèjusį atliekamų užduočių transakciju metu sudètingumą. Todèl, pasikeitus sąlygoms bei siekiant ir toliau kasti Bitcoin valiutą reikèjo investuoti ị galingesnę kompiuterinę ịrangą, siekiant atlikti sudètingesnès užduotis bei padengti elektros sąnaudas, kasant kriptovaliutą ịprastu kompiuteriu.

Nuo 2017 liepos iki 2018 sausio Bitcoin valiutą palankiausia buvo igyti, ją kasant naudojant ịrangą, kuri būtų pritaikyta arba pajègi šiam procesui. Šị igijimo būdą dar galima 
išskirti ị dvi kategorijas:

- naudojant, kompiuterinę įrangą, skirtą tik kriptovaliutos kasimui;

- naudojant kompiuterinę ịrangą, kuri gali būti panaudojama ne tik kriptovaliutų kasimui, tačiau yra pajègi kasti kriptografinius pinigus.

Pirmoje kategorijoje yra ịvardijama tokia kompiuterinè įranga, kaip „Antminer“ kompiuteriai, kurie yra skirti tik kriptovaliutos kasimui ir negali būti pritaikyti kitokių užduočių atlikimui. Tuo tarpu antroje kategorijoje išskiriama kompiuterinè ịranga, kuri yra skirta ne tik kriptovaliutų kasimui, tai yra kriptografinių pinigų kasimui naudojant tam tinkančias kompiuterines vaizdo plokštes, kurios yra pakankamai galingos kasimo užduočių atlikimui, dažnai pasitelkiant kelias arba keliolika, siekiant užtikrinti kriptovaliutos kasimo efektyvumą. Šiose kategorijose išskiriamos įrangos palyginimas pateiktas 1 lentelèje.

Kriptovaliutų kasimo įrangų palyginimas (Bitcoin kasimo įranga, 2019)

1 lentelè

\begin{tabular}{|c|c|}
\hline $\begin{array}{l}\text { Kategorijos įrangos } \\
\text { apibūdinimas }\end{array}$ & Kategorijos įrangos palyginimo kriterijai \\
\hline $\begin{array}{l}\text { kompiuterinè ịranga skirta tik } \\
\text { kriptovaliutos kasimui }\end{array}$ & $\begin{array}{l}\text { Paprasta naudoti; } \\
\text { Mažesnė kaina (nuo } 500 \text { Eur iki } 3000 \text { Eur); } \\
\text { Sunaudoja mažiau elektros; } \\
\text { Skirta tik kriptovaliutos kasimui. }\end{array}$ \\
\hline $\begin{array}{l}\text { kompiuterinè iranga, kuri gali } \\
\text { būti panaudojama ne tik } \\
\text { kriptovaliutų kasimui }\end{array}$ & $\begin{array}{l}\text { Sudètingesnis naudojimas; } \\
\text { Didesnè kaina (nuo } 200 \text { Eur iki } 500 \text { Eur, tačiau kasimo } \\
\text { operacijoms atlikti yra naudojama nuo kelių iki } \\
\text { keliolikos vaizdo plokščių); } \\
\text { Sunaudoja daugiau elektros; } \\
\text { Gali būti panaudota ne tik kriptovaliutos kasimui. }\end{array}$ \\
\hline
\end{tabular}

1 lentelès duomenys rodo, kad kompiuterinè įranga skirta tik kriptovaliutos kasimui (pvz.: Antminer kompiuteris) pasižymi paprastesniu naudojimu, yra pigesnè, palyginus su reikalingomis investicijomis, siekiant kriptovaliutą kasti kompiuterine ịranga, kuri gali būti panaudojama ne tik kriptovaliutu kasimui. Norint efektyviai kasti kriptovaliutą vaizdo plokštemis, tektų ị kompiuterinę ịrangą investuoti nuo 400 Eur iki 5000 Eur. Be to, kompiuterinė įranga, skirta tik kriptovaliutos kasimui, sunaudoja mažiau elektros, kas yra svarbu atsižvelgiant i tai, kad ši kompiuterinè įranga įprastai dirba be pertraukų. To pasėkoje būtų galima daryti išvadą, kad, norinti kasti kriptografinius pinigus, labiau apsimoka naudoti specialią kompiuterinę ịrangą, tačiau, reikètų ịvertinti ir tai, jog šios kompiuterinès įrangos pasiūla, palyginus su kompiuterinių vaizdo plokščių tinkančių kriptografinių pinigų kasimui, yra žymiai mažesnè, todèl galima daryti prielaidą, kad praktikoje dažniau šiam procesui buvo naudojamos kompiuterinès vaizdo plokštès. Be to, remiantis statistiniais duomenimis (All currencies, 2019), Bitcoin kriptovaliutos paklausa yra gana nepastovi. Todėl investavus ị kompiuterinę įrangą, kuri, sumažèjus kriptovaliutos paklausai, nebegalètų būti efektyviai naudojama bei parduota nepatiriant didelių nuostolių, yra per daug rizikinga. Tuo tarpu tokia kompiuteriné technika, kaip vaizdo plokštès gali būti panaudota ir kitose srityse, tai reiškia, kad sumažèjus kriptografinių pinigų paklausai, kompiuterinių vaizdo plokščių paklausa neturèti stipriai pakisti, todèl jas būtų galima parduoti, nepatiriant didesnių nuostolių. Vertinant įrangos kriptovaliutos kasimui pasirinkimą bei perleidimo galimybes, reikètų atsižvelgti ir ị kompiuterinès įrangos nusidèvèjimą kriptografinių 
pinigų kasimo procese.

Kriptovaliutos ịgijimo būdas, ją kasant išsinuomojus kompiuterinę ịrangą, išpopuliarejo nuo 2018 m. sausio iki 2019 m. sausio mèn. Šiuo laikotarpiu i kriptovaliutos kasimo rinką pradèjo veržtis imonès, atidarydamos šios valiutos kasimo kasyklas, tai yra kasdamos kriptografinius pinigus dideliais mastais. Šiuo laikotarpiu Bitcoin verte bei rinkos kapitalizacija mažèja (All currencies, 2019). Tokia tendencija sąlygojo, jog kriptovaliutų kasimo rinka tapo perpildyta, o populiarejant šiai kriptovaliutai padidejo transakciju ja kiekis, to pasèkoje mažèjo atlygis už vykdomas užduotis, be to, užduotys tapo dar sudètingesnès. Todèl šiai rinkai pasiekus tokị lygi, kai atidaromos kriptografinių pinigų kasyklos išstūmè iš kasimo rinkos individualius kriptovaliutos kasëjus, sumažèjo šių alternatyvių pinigų paklausa ir kaina. Taigi, laikotarpiu nuo 2018 sausio mèn. iki 2019 m. sausio mèn. Bitcoin kriptovaliutos kasimo rinkoje atsirado įmoniu užsiimančiu tuo žymiai didesniais mastais nei individualūs asmenys, o įmonèms perèmus kriptovaliutų kasimo rinką, atsirado kasimo ịrangos nuomos paslauga. Tai asmenims sudaré galimybę už tam tikrą sumą išsinuomoti dalị kriptografinių pinigų kasyklos ịrangos, norimos valiutos kasimui. Šios paslaugos kainą sudaré tikètina gauti ịmonių ekonominè nauda, kasant atitinkamą kriptovaliutą per atitinkamą laikotarpị. Tačiau, atsižvelgiant ị tai, jog kriptografinių pinigų vertẻ gali žymiai kisti per trumpą laiko tarpą, i̇monės, suteikiančios tokias paslaugas, dažnai šiek tiek mažino ịrangos nuomos kainas, palyginus su galimai iškastos kriptovaliutos verte, noredamos kasamas rizikingas pajamas iškeisti i garantuotas nuomos pajamas. Visgi asmenims perkantiems šias paslaugas, galimybė gauti iš tokios paslaugos didesnès ekonominès naudos yra mažos. Dėl šių priežasčių šios paslaugos nėra populiarios.

Pats paprasčiausias kriptografinių pinigų igijimo būdas yra jų pirkimas už tradicinius pinigus. Šis būdas yra dažnai naudojamas fizinių asmenų, kurie investuoja ị nagrinèjamą valiutą, siekdami pasipelnyti iš šio turto vertès kitimo.

Išnagrinejjus kriptovaliutos igijimo būdus bei populiariausios valiutos Bitcoin rinkos kapitalizacijos normą nuo 2013 m. iki 2019 m., 2 lentelèje pateikiamas šios kriptovaliutos kasimo būdų vertinimas laiko retrospektyvoje.

\section{Kriptovaliutos kasimo būdų vertinimas laiko retrospektyvoje}

2 lentele

\begin{tabular}{|l|l|}
\hline \multicolumn{1}{|c|}{ Laikotarpis } & \multicolumn{1}{c|}{ Perspektyviausias kriptvaliutų kasimo būdas } \\
\hline $\begin{array}{l}2013 \mathrm{~m} \text {. liepa }-2017 \\
\text { m. liepa }\end{array}$ & $\begin{array}{l}\text { Kriptovaliuta buvo efektyvu ísigyti, ją kasant nuosavais } \\
\text { kompiuteriais. }\end{array}$ \\
\hline $\begin{array}{l}2017 \mathrm{~m} \text {. liepa }-2018 \\
\text { m. sausis }\end{array}$ & $\begin{array}{l}\text { Kriptovaliutai populiarėjant fiziniai ir juridiniai asmenys jos } \\
\text { kasimui pradejo naudoti labiau tam tinkančias kompiuterines } \\
\text { technologijas, kurios reikalavo investicijų. }\end{array}$ \\
\hline nuo 2018 m. sausio & $\begin{array}{l}\text { I kriptovaliutos kasimo rinką pradèjo veržtis ir palaipsniui } \\
\text { peremė imonės atidarančios kriptografinių pinigu kasimo } \\
\text { kasyklas. Todèl paskutiniu metu individualus kriptografiniu } \\
\text { pinigu kasimas yra vis mažiau efektyvus. }\end{array}$ \\
\hline
\end{tabular}

\section{Kriptovaliutos kasimo ir naudojimo vertinimas}

Vertinant kriptovaliutos kasimą, svarbu išnagrinèti kasejjų gaunamą naudą, kurią atspindi 2 paveikslas. 2 paveikslo duomenys rodo, kad iki 2016 m., kai kriptovaliutos nebuvo populiarios, kasimo užmokestị sąlygojo žemas kriptovaliutos vertès lygis. Situacija pasikeite $2017 \mathrm{~m}$. išaugus 
kriptovaliutų populiarumui bei kainai. $2017 \mathrm{~m}$. pabaigoje Bitcoin kaina buvo pasiekusi didžiausią vertę (All currencies, 2019), todèl daugelis norejjo pasipelnyti kasdami šią valiutą. Nuo 2018 metŭ, kai kriptovaliutų, tame tarpe ir Bitcoin, verte pradèjo kristi, ženkliai sumažèjo ir šios veiklos pajamos, kurios pasiekè iki $2016 \mathrm{~m}$. buvusị lygị.

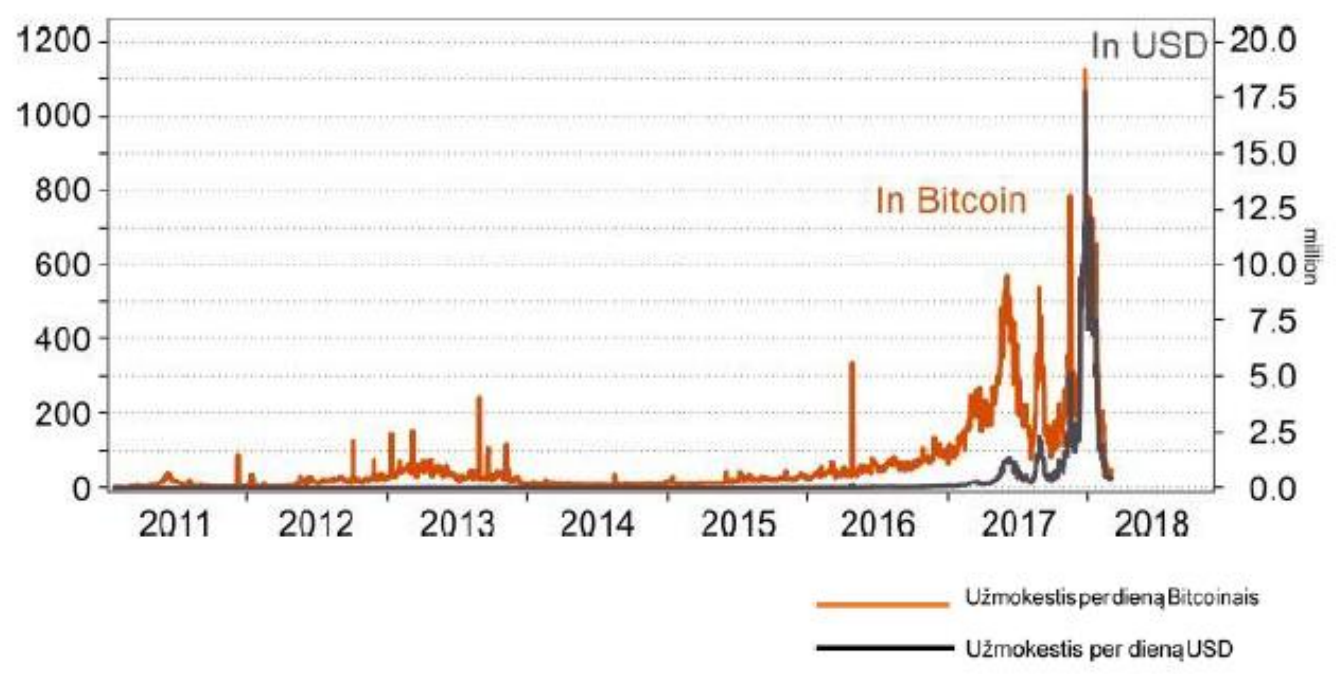

2 pav. Kriptovaliutos kasëjų užmokestis (Mačiulis, 2018)

3 paveikslas atspindi Bitcoin valiutos kainos ir sandoriu ja skaičiaus pokytį, vertinant duomenis $2016 \mathrm{~m}$. sausio mèn. 01d. atžvilgiu. 3 paveikslo duomenys rodo, kad sandorių šia valiuta skaičiaus pasikeitimas reikšmingos įtakos jos kainos pasikeitimui nedare ir kito pakankamai stabiliai nagrinejjamu laikotarpiu.

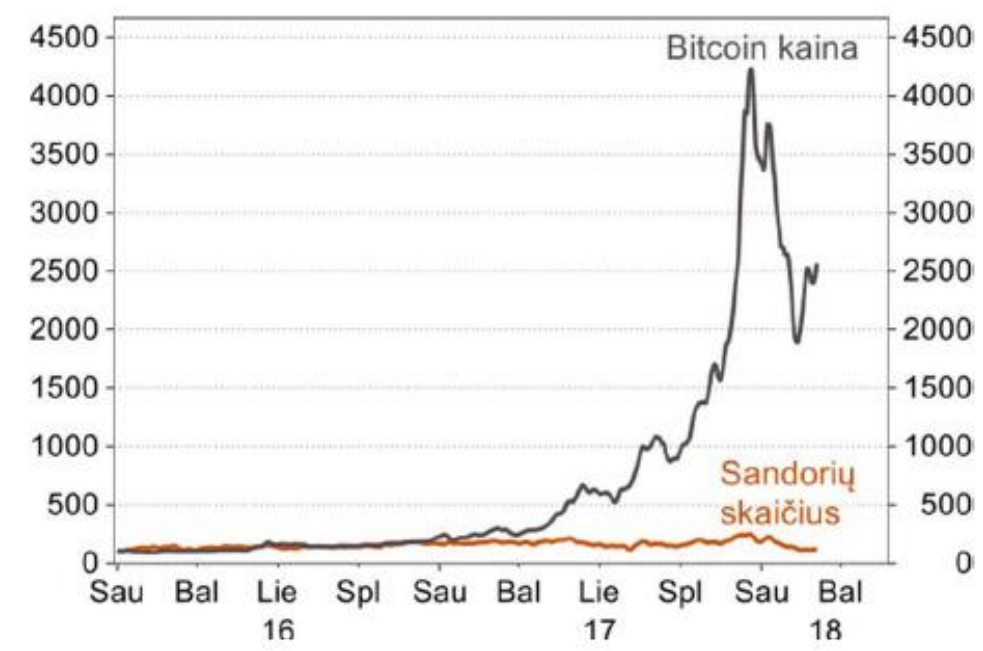

3 pav. Bitcoin kainos ir sandorių skaičiaus pasikeitimas 2016-2018 m.

(Mačiulis, 2018) 
Vertinant populiariausios kriptovaliutos Bitcoin naudojimą, svarbu atsižvelgti $\mathfrak{i}$ šios valiutos naudijimą atsisaitymo procese. 4 paveiksle yra pateiktas sandorių per sekundę skaičius, atsiskaitant populiariausiomis pinigu pervedimo platformomis, kuris rodo, kad nežiūrint didelio Bitcoin valiutos populiarumo, atsiskaitant Visa kortelemis vis dar lieka populiariausia priemone. Ir nors 2017 metų pabaigoje kriptovaliutų rinka išaugo, tačiau atsiskaitymų jomis lygis nedidejjo tuo pačiu tempu. Todèl peršasi išvada, jog asmenys, bandè ịvairiais būdais ịsigyti kriptovaliutų, siekdami pasipelnyti iš jų augančios kainos, t.y. dauguma šios kriptovaliutos vartotojų labiau ieškojo, kur investuoti pinigus, nei vykdyti operacijas kriptovaliuta.

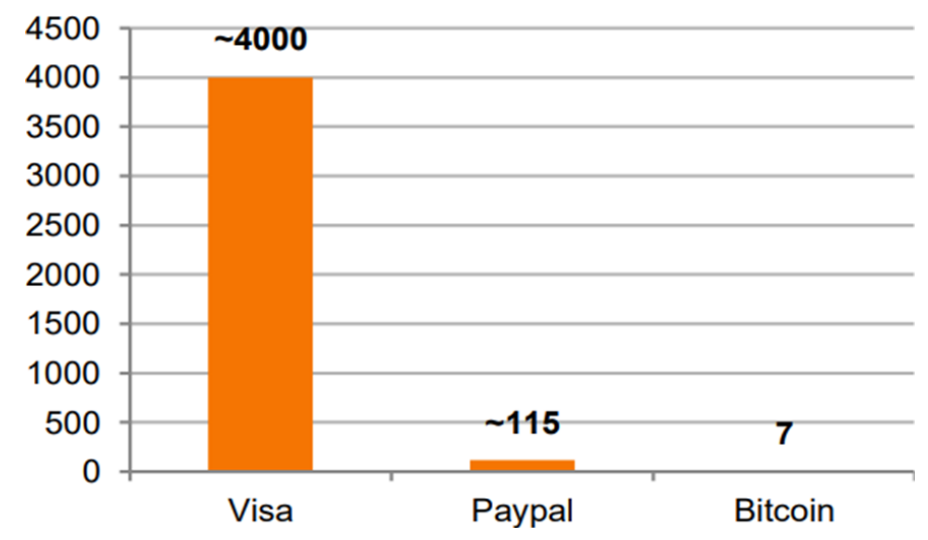

4 pav. Sandorių per sekundę skaičius (Mačiulis, 2018)

Be to, vertinant kriptovaliutos ir kitų atsiskaitymo platformų naudojimą, svarbu įvertinti ir tokius veiksnius, kaip elektros $\mathrm{kWh}$ sunaudojimas. Vienas sandoris Bitcoin kainuoja apie 780 $\mathrm{kWh}$, kai vienas sandoris Visa - 0,1 kWh (Mačiulis, 2018). Todèl, priimant sprendimus dèl kriptovaliutos igijimo ir naudojimo, svarbu atsižvelgti ị visus aspektus.

\section{Išvados}

Kriptovaliuta apibūdinama, kaip skaitmeniniai pinigai ar turtas, išreikštas el. būdu. Atsiskaitymai tokia valiuta yra greitesni, pigesni bei saugesni. Jai netaikomas reguliacinis ir kontrolès mechanizmas. Tačiau kriptovaliutos turèjimuas yra susijęs su didele jos nuvertèjimo rizika.

Kriptovaliuta gali būti igyjama dviem būdais: ją perkant ir kasant arba pasigaminant. Vertinant populiariausios valiutos Bitcoin kasimą laiko retrospektyvoje, galima būtu išskirti tris laikotarpius. Nuo 2013 m. liepos iki 2017 m. liepos, kai šią kriptovaliutą buvo efektyvu igyti, ją kasant nuosavais kompiuteriais. Nuo 2017 m. liepos iki 2018 m. sausio, kai kriptovaliutai populiarejant fiziniai ir juridiniai asmenys jos kasimui pradèjo naudoti labiau tam tinkančias kompiuterines technologijas, kurios reikalavo investicijų. Bei nuo $2018 \mathrm{~m}$. sausio, kai i kriptovaliutos kasimo rinką pradèjo veržtis ir palaipsniui perèmé įmonès atidarančios kriptografinių pinigų kasimo kasyklas. Todèl paskutiniu metu individualus kriptografinių pinigu kasimas yra vis mažiau efektyvus.

Vertinant kriptovaliutos kasimą bei naudojimą, svarbu atsižvelgti ị tokius aspektus, kaip jos vertès ir sandorių ja kitimas, taikymas populiariausiose pinigų pervedimo platformose, išteklių sunaudojimas vienam sandoriui ir kt. 


\section{References}

All crytocurrences. (2019). Coin Market Cap. [Electronic resource]. Retrieved from https://coinmarketcap.com/all/views/all/. [in English].

Bartkus, $\check{C}$. (2019). Investavimo $i$ Bitcoin rizikingumas, Studijos kintančioje verslo aplinkoje, straipsniu rinkinys, 2019. [Electronic resource]. Retrieved from http://www.leda.lt/Studijos_kintancioje_verslo_aplinkoje_2019.pdf\#page=27. [in Lithuanian]. Bitcoin kasimo ìranga (bitcoin mining hardware). (2019). [Electronic resource]. Retrieved from https://www.1a.lt/kp/bitcoin-kasimo-iranga-bitcoin-mining-hardware/v. [in Lithuanian].

Ispejjimas dèl virtualių valiutu. (2014). Lietuvos bankas. [Electronic resource]. Retrieved from http://www.lb.lt/uploads/documents/files/news/ispejimas_bitcoin.pdf.pdf. [in Lithuanian].

Karataeva, G. E., \& Siniavskii, N. N. (2019). Cryptocurrency as an alternative investment tool. Interactive science, 5(39), 56-58. DOI:10.21661/r-496802. [in Russian].

Kuo Chuen, D. L.; Pak Nian, L. (2015). Introduction to Bitcoin. Bitcoin, Innovation, Financial Instruments, and Big Data. [Electronic resource]. Retrieved from https://www.sciencedirect.com/science/article/pii/B9780128021170000011. DOI: 10.1016/B9 78-0-12-802117-0.00001-1. [in English].

Limba, T., Stankevičius, A., Andrulevičius, A. (2019). Cryptocurrency as Disruptive Technology: Theoretical Insighs. Entrepreneurship and Sustainability Issues, Vol. 6, Nr 4 (June), 2068-2080. DOI: 10.9770/jesi.2019.6.4(36). [in English].

Mačiulis, N. (2018). Kriptovaliutos: revoliucija ar burbulas. [Electronic resource]. Retrieved from http://www.lsta.lt/files/events/180306\%20Valstybe/Nerijus\%20Maciulis.pdf. [in Lithuanian].

Mikołajewicz-Woźniak, A., Scheibe, A. (2015). Virtual currency schemes - the future of financial services. Foresight, Vol. 17, Issue 4, 365-377. DOI: 10.1108/FS-04-2014-0021. [in English].

Nasir, M.A., Huynh, T.L.D., Sang Phu Nguyen, S.P., Duong, D. (2019). Forecasting cryptocurrency returns and volume using search engines. Financial Innovation, 5:2, 1-13. DOI: 10.1186/s40854-018-0119-8. [in English].

Şoavă, G., Mehedințu, A., Sitnikov, C. (2016). Virtual Currency "Bitcoin" - Challenges and Controversies. Annals of the „Constantin Brâncuşi” University of Târgu Jiu, Economy Series, Issue 3. [Electronic resource]. Retrieved from http://www.utgjiu.ro/revista/ec/pdf/201603/46_SOAVA,\%20MEHEDINTU,\%20SITNIKOV.pdf. [in English].

Subačius, A., Subačiene, R. (2019). Kriptovaliuta: privalumai ir trūkumai. Buhalterinès apskaitos teorija ir praktika, Nr. 19. DOI: 10.15388/batp.2019.1. [in Lithuanian].

Volosovych, S., Baraniuk, Y. (2018). Tax control of cryptocurrency transactions in Ukraine. Banks and Bank Systems, Vol, 13, Is, 2, 89-106. DOI: 10.21511/bbs.13(2).2018.08. [in English]. 